\title{
HUBUNGAN ASUPAN PROTEIN DAN KEBIASAAN MAKAN PAGI TERHADAP KADAR HEMOGLOBIN PADA ANAK USIA 9-12 TAHUN DI TAMBAKLOROK SEMARANG UTARA
}

\author{
Diajeng Dian Rahana Ningsih ${ }^{1}$, Binar Panunggal ${ }^{1}$, Adryan Pramono ${ }^{1}$, Deny Yudi Fitranti ${ }^{1}$ \\ ${ }^{1}$ Departemen Ilmu Gizi, Fakultas Kedokteran, Universitas Diponegoro \\ Jln. Prof. H. Soedarto, SH., Semarang, Telp (024) 8453708, Email : gizifk@ undip.ac.id
}

\begin{abstract}
Backgrounds: Anemia in children provides some impacts on growth, development, and body immunity. One of the factors causing the anemia in school-age children is insufficient intake of nutrients, especially iron and protein. Insufficiency of iron and protein intake could interfere the process of red blood cell formation and transportation of nutrients throughout the body. The intake of iron and protein could be gained only from the breakfast menu.

Aim: This research is aimed to analyze the relationship between protein intake and the habit having breakfast toward haemoglobin $(\mathrm{Hb})$ in 9-12 years old children.

Methods: This research used cross-sectional design. In this research, simple random sampling was used as a sampling method. The subject of this research was 62 students in which their age were 9-12 years old. This research was conducted in Tambaklorok Village, North Semarang. Haemoglobin level was analyzed by using cyanmethemoglobin method. The data of nutrient intake was obtained through interviews by using a Semi-Quantitative Food Frequency Questionnaire (FFQ-SQ), then it was analyzed by using Nutrisurvey. The data was analyzed by using Rank Spearman.

Results: The prevalence of nutritional status of the subject based on indicators with body mass index (BMI) was 50\% underweight. There were 3,2\% of the subjects who were not accustomed to have breakfast. The mean haemoglobin levels of the subject on this research was $12.9 \pm 0.97 \mathrm{~g} / \mathrm{dl}$. The average of the protein intake of the subject was only $42.5 \pm 11.81$ g/day.

Conclusion: There is a relationship between protein intake and the habit of having breakfast toward haemoglobin in 912 years old children.
\end{abstract}

Keywords: Haemoglobin, protein intake, breakfast, children

\begin{abstract}
ABSTRAK
Latar belakang: Anemia pada anak memberikan dampak terhadap proses pertumbuhan, perkembangan dan kekebalan tubuh. Salah satu faktor penyebabnya adalah ketidak cukupan asupan zat gizi terutama zat besi dan protein. Ketidak cukupan asupan zat besi dan protein mengganggu proses pembentukan sel darah merah dan transportasi zat gizi ke seluruh tubuh. Asupan zat besi dan protein dapat diperoleh salah satunya dari menu makan pagi.

Tujuan: Penelitian ini bertujuan untuk menganalisis hubungan asupan protein dan kebiasaan makan pagi terhadap kadar hemoglobin $(\mathrm{Hb})$ pada anak usia 9 - 12 tahun.

Metode: Penelitian ini menggunakan desain cross sectional (belah lintang). Metode pengambilan sampel menggunakan simple random sampling. Subjek penelitian ini adalah anak usia $9-12$ tahun sejumlah 62 siswa. Penelitian dilakukan di SD Islam Taqwiyatul Wathon, diwilayah kelurahan Tambaklorok, kecamatan Semarang Utara. Kadar hemoglobin dianalisis menggunakan metode Cyanmethemoglobin. Data asupan zat gizi diperoleh melalui wawancara menggunakan kuesioner Semi-Quantitative Food Frequency Questionnaire (FFQ) selanjutnya dianalisis menggunakan Nutrisurvey. Analisis data menggunakan uji Rank-Spearman.

Hasil: Prevalensi status gizi subjek berdasarkan indikator IMT/U Sebanyak 50\% underweight. Sebanyak 8,0\% subjek tidak memiliki kebiasaan makan pagi. Rerata kadar Hemoglobin subjek pada penelitian ini yaitu sebesar 12,9 $\pm 0,97 \mathrm{~g} / \mathrm{dl}$. Rerata asupan protein subjek hanya sebesar 42,5 $\pm 11,81$ g/hari. Angka ini lebih kecil dari jumlah yang dianjurkan AKG yaitu $60 \mathrm{~g} / \mathrm{hari}$. Terdapat hubungan antara asupan protein, kebiasaan makan pagi dan kadar hemoglobin pada anak usia 9-12 tahun.
\end{abstract}

Kesimpulan: Terdapat hubungan antara asupan protein, makan pagi terhadap kadar hemoglobin pada anak usia 9-12 tahun.

Kata kunci: kadar hemoglobin, asupan protein, kebiasaan makan pagi, anak usia sekolah

\section{PENDAHULUAN}

Anemia defisiensi besi pada anak usia sekolah dasar saat ini menjadi masalah gizi yang serius di Indonesia. ${ }^{1}$ Anemia defisiensi besi pada anak usia sekolah dasar menjadi masalah kesehatan yang belum terselesaikan karena prevalensinya lebih dari standar nasional yaitu $\geq 20 \% .{ }^{2} \mathrm{Hal}$ ini ditandai dengan tingginya angka prevalensi anemia pada anak usia 5 12 tahun yang mencapai 29\% pada tahun 2014 menurut Riset Kesehatan Dasar. ${ }^{2}$ Menurut World 
Health Organization (WHO) mencatat bahwa prevalensi anemia defisiensi besi di dunia yang terdapat pada anak usia sekolah mencapai $25,4 \% .^{3}$

Anemia defisiensi besi pada anak disebabkan karena kehilangan darah secara kronis, asupan dan serapan zat besi yang tidak adekuat, dan peningkatan kebutuhan zat gizi. ${ }^{4}$ Beberapa faktor saling terkait seperti jumlah zat besi pada makanan yang tidak cukup karena rendahnya konsumsi protein adalah salah satu penyebab adanya anemia pada anak. ${ }^{1,4}$ Penyebab anemia gizi besi pada anak sekolah umumnya disebabkan karena kekurangan asupan zat gizi khususnya besi dan zat-zat gizi lain yang membantu penyerapan dan metabolisme besi. ${ }^{4}$ Menurut WHO nilai batas ambang untuk anemia anak umur 5 - 12 tahun adalah apabila $\mathrm{Hb}>10,0 \mathrm{~g} / \mathrm{dl} .^{3}$

Penyerapan zat besi yang tidak adekuat bisa disebabkan salah satunya karena kurangnya asupan protein. Hal ini karena protein berperan sebagai komponen pembentuk transporter zat besi dalam tubuh, yaitu transferin. Asupan protein yang kurang maka ketersediaan transferin dalam tubuh berkurang dan menyebabkan zat besi yang diserap juga berkurang. ${ }^{4}$ Selain itu, protein juga berperan dalam pembentukan ferritin. Dalam tubuh mausia, besi tidak terdapat bebas, tetapi berikatan dengan molekul protein memebentuk ferritin. Ferritin merupakan suatu kompleks protein dan besi di dalam tubuh ${ }^{1,4}$ Protein ini juga sebagai alat angkut terhadap kadar hemoglobin yaitu mengangkut oksigen dalam eritrosit. Selain itu, di dalam otot protein pengangkut oksigen disebut mioglobin. Ion besi diangkut dalam plasma darah oleh transferrin dan disimpan dalam hati sebagai kompleks dengan ferritin. ${ }^{4}$

Asupan serat yang terdapat pada sayuran, diketahui dapat menghambat penyerapan zat besi didalam tubuh (inhibitor factors). ${ }^{6}$ Zat yang ditemukan dalam serat pada sayuran, yang menghambat penyerapan zat besi yaitu asam oksalat dan asam fitat. Asam oksalat dan asam fitat ini yang bekerja dan bersifat mengikat besi sehingga dapat mengganggu penyerapan zat besi. ${ }^{5}$ Asupan zat besi berperan penting dalam pembentukan hemoglobin. Asupan besi yang cukup belum tentu akan menghasilkan hemoglobin yang cukup bila tidak di imbangi dengan keterlibatan atau keberadaan zat gizi lainnya. ${ }^{5,6}$

Selain beberapa faktor asupan besi, asupan makan pagi juga berpengaruh terhadap kadar hemoglobin pada anak. Penelitian yang dilakukan terhadap 60 siswa sekolah dasar ini, menunjukkan bahwa terdapat hubungan yang signifikan antara asupan makan pagi dengan kadar hemoglobin anak. Makan pagi merupakan suatu kebiasaan anak sekolah yang dapat meningkatkan konsentrasi belajar. Kebiasaan makan pagi pada anak merupakan makanan pokok sebelum berangkat ke sekolah. Terdapat dua kategori mengenai makan pagi, yaitu: mempunyai kebiasaan makan pagi bila dalam seminggu minimal empat sampai tujuh kali makan pagi dan satunya lagi tidak mempunyai kebiasaan makan pagi bila tidak sama sekali atau kurang dari tiga kali dalam seminggu. Asupan makan pagi juga sangat berperan penting terhadap pemenuhan gizi seimbang pada anak. ${ }^{7}$ Asupan makan pagi memberikan kontribusi besar pada peningkatan konsentrasi anak, dan peningkatan pada energi harian dan asupan zat gizi pada anak. Makan pagi menyediakan $16 \%$ dari asupan kalsium, besi, tiamin, dan asupan folat, seperlima asupan seng. ${ }^{7}$ Anak yang sering melewatkan makan pagi memiliki asupan gizi lebih rendah dibandingkan dengan anak yang terbiasa makan pagi. Sementara kekurangan gizi dan kekurangan zat gizi mikro telah terbukti berdampak pada kesehatan fisik, mental dan sosial. Anak yang tidak makan pagi beresiko terkena anemia. ${ }^{8,9}$

\section{METODE PENELITIAN}

Penelitian dilakukan di SD Islam Taqwiyatul Wathon, Kelurahan Tambaklorok, Kecamatan Semarang Utara, Kota Semarang. Penelitian ini dimulai pada bulan Agustus sampai Oktober 2015. Penelitian ini dilakukan di SD Islam Taqwiyatul Wathon kelurahan tambaklorok karena tempat atau lingkungan disana masih kurang sehat banyak sampah yang berserakan, genangan air disekitar sekolah tersebut dan bau yang sangat menyengat. Penelitian ini termasuk dalam ruang lingkup gizi masyarakat dengan rancangan cross-sectional (belah lintang). Populasi pada penelitian ini adalah siswasiswi kelas 4, 5, 6 di SD Islam Taqwiyatul Wathon Semarang sejumlah 123 anak. Subjek dipilih berdasarkan kriteria inklusi, yaitu anak berusia 9-12 tahun, tidak penyakit infeksi (Diare, TBC, ISPA, Pneumonia, dan penyakit infeksi lainnya), untuk subjek perempuan belum mengalami menstruasi. Seluruh subjek terpilih harus telah mendapat izin atau persetujuan dari orang tua dengan menandatangani informed consent. Sedangkan kriteria eksklusi antara lain subjek pindah rumah dan meninggal dunia. Pemilihan subjek penelitian ini dilakukan dengan metode simple random sampling. Berdasarkan perhitungan rumus besar sampel, diperoleh jumlah sampel minimal sebanyak 62 anak.

Variabel bebas penelitian ini adalah asupan protein dan kebiasaan makan pagi. Data asupan protein diperoleh dengan melakukan wawancara menggunakan formulir Semi-Quantitative Food Frequency Questionnaire (FFQ-SQ). Data asupan zat gizi yang diperoleh kemudian diolah menggunakan program Nutrisurvey. Rerata asupan protein kemudian dibandingkan dengan AKG 2013. Nilai 
AKG protein pada anak usia 7 - 9 tahun adalah $49 \mathrm{~g}$, dan untuk anak laki- laki usia 10 - 12 tahun adalah 56 g. Untuk nilai AKG pada anak perempuan usia $10-$ 12 tahun apabila terdapat $60 \mathrm{~g}$. Apabila asupan protein kurang dari nilai $\mathrm{AKG}$ diketahui sebagai kurang. Apabila supan protein lebih atau sama dengan AKG dikategorikan sebagai cukup. Kemudian kebiasaan makan pagi adalah frekuensi makan pagi yang dilakukan sebelum kegiatan sekolah dalam seminggu. Bila dikategorikan memiliki kebiasaan makan pagi jika dalam seminggu 4-7 kali makan pagi, dan dikatakan tidak memiliki kebiasaan makan pagi jika dalam seminggu tidak sama sekali makan pagi. Dan di nyatakan kadang - kadang makan pagi apabila seorang anak dalam seminggu melakukan kegiatan makan pagi kurang dari 4 kali dalam seminggu. Data kebiasaan makan pagi diperoleh menggunakan metode wawancara menggunakan kuisioner terstruktur. Pemeriksaan hemoglobin menggunakan metode Cyanmethemoglobin di laboratorium Sarana Medika. Diketahui anemia pada anak apabila terdapat nilai $\mathrm{Hb}$ dibawah $<11,5 \mathrm{mg} / \mathrm{dl}$ untuk anak usia $2-11$ tahun. Untuk anak laki - laki pada usia >12 tahun apabila nilai $\mathrm{Hb}$ dibawah $<13 \mathrm{mg} / \mathrm{dl}$, dan untuk anak perempuan dikatakan anemia apabila nilai $\mathrm{Hb}<12$ $\mathrm{mg} / \mathrm{dl}$.

Data yang telah diperoleh kemudian dianalisis dengan menggunakan uji statistik. Uji normalitas menggunakan Kolmogorov-Smirnov dan uji korelasi menggunakan uji Rank Spearman.

\section{HASIL}

Sekolah Dasar (SD) Islam Taqwiyatul Wathon merupakan satu-satunya sekolah dasar yang berdekatan dengan lokasi pelelangan ikan Tambaklorok, kota Semarang. Sanitasi di lingkungan tersebut masih tergolong kurang bersih dikarenakan banyaknya tumpukan-tumpukan sampah dan terdapat genangan air di daerah tersebut, serta menimbulkan aroma yang sangat menyengat.

\section{Karakteristik Subjek Penelitian}

Subjek penelitian ini terdiri dari $32(51,6 \%)$ anak laki-laki dan 30 anak perempuan $(48,4 \%)$. Data dapat dilihat pada tabel 1 . Sebanyak $2(3,2 \%)$ anak termasuk dalam kategori anemia. Subjek yang tergolong memiliki kebiasaan makan pagi sebanyak $21(33,8 \%)$ anak, yang tergolong kadang-kadang makan pagi sebanyak $36(58,0 \%)$ anak dan tidak memiliki kebiasaan makan pagi sebanyak $5(8,0 \%)$ anak. Data dapat dilihat pada tabel 1.

Subjek pada penelitian ini yang tergolong anemia sebanyak $2(3,3 \%)$ dan tidak tergolong anemia sebanyak $60(96,7 \%)$ anak. Sebanyak 21 $(33,8 \%)$ anak pada penelitian ini terbiasa makan pagi, $5(8,0 \%)$ anak tidak memiliki kebiasaan makan pagi, dan $36(58,0 \%)$ anak memiliki kebiasaan kadangkadang makan pagi. Subjek penelitian ini terdapat 50 (50\%) anak yang tergolong kurus.

Tabel 1. Karakteristik Subjek Penelitian

\begin{tabular}{lll}
\hline Variabel & n & $(\mathbf{\%})$ \\
\hline Usia & & \\
9 & 26 & $(41,9)$ \\
10 & 25 & $(40,3)$ \\
11 & 9 & $(14,5)$ \\
12 & 2 & $(3,2)$ \\
\hline Jenis kelamin & & \\
Laki-laki & 32 & $(51,6)$ \\
Perempuan & 30 & $(48,4)$ \\
\hline Status gizi (IMT/U) & & \\
Kurus & 31 & $(50,0)$ \\
Normal & 29 & $(46,7)$ \\
Obesitas & 2 & $(3,2)$ \\
\hline Status Anemia & & \\
Anemia & 2 & $(3,30)$ \\
Non-anemia & 60 & $(96,7)$ \\
\hline Kebiasaan makan pagi (sarapan) & & \\
Terbiasa & & \\
Tidak terbiasa & 21 & $(33,8)$ \\
Kadang-kadang & 5 & $(8,0)$ \\
& 36 & $(58,0)$ \\
\hline
\end{tabular}

Tabel 2. Karakteristik Asupan Zat Gizi Subjek Penelitian

\begin{tabular}{lrr}
\hline Asupan & n & \% \\
\hline $\begin{array}{l}\text { Asupan Seng } \\
\text { kurang } \\
\text { cukup }\end{array}$ & 62 & 100 \\
\hline Asupan Besi & 0 & 0 \\
Kurang & 59 & \\
Cukup & 3 & 45,1 \\
\hline Asupan Vitamin C & & \\
Kurang & 47 & 75,8 \\
Cukup & 15 & 24,1 \\
\hline Asupan Protein & & \\
Kurang & 45 & 72,5 \\
Cukup & 17 & 27,4 \\
\hline Asupan Serat & & \\
Kurang & 62 & 100 \\
Cukup & 0 & 0 \\
\hline
\end{tabular}

\section{Asupan Zat Gizi}

Tabel 2 menggambarkan kecukupan asupan zat gizi subjek seperti asupan seng, besi, vitamin, protein, dan serat. Sebanyak 62 anak (100\%) memiliki asupan seng yang kurang dari AKG. Asupan seng yang dikonsumsi subjek sebagian besar diperoleh dari produk perikanan. Produk perikanan yang sering dikonsumsi subjek pada penelitian ini yaitu ikan bandeng, ikan kipper, ikan mujair, ikan belanak, kerang, udang, dan kepiting. 
Sebanyak 59 anak $(95,1 \%)$ memiliki asupan besi kurang. Sebanyak 47 anak $(75,8 \%)$ memiliki asupan vitamin $\mathrm{C}$ dibawah nilai AKG yaitu $50 \mathrm{~g} /$ hari, terdapat 45 anak $(72,5 \%)$ memiliki asupan protein kurang dari $\mathrm{AKG}$, angka yang terdapat di penelitian ini juga lebih kecil dari yang di anjurkan AKG, yaitu $56 \mathrm{~g} /$ hari untuk anak laki-laki dan $60 \mathrm{~g} /$ hari untuk anak perempuan dan 62 (100\%). Sebanyak 62 anak (100\%) memiliki asupan serat dibawah nilai AKG.

Tabel 3. Hubungan Kebiasaan Makan Pagi, Asupan Protein dan Kadar Hemoglobin

\begin{tabular}{llcc}
\hline $\begin{array}{l}\text { Variabel } \\
\text { Independen }\end{array}$ & $\begin{array}{l}\text { Variabel } \\
\text { Dependen }\end{array}$ & r & p \\
\hline Makan Pagi & Hemoglobin & 0,539 & 0,001 \\
Protein & Hemoglobin & 0,286 & 0,024
\end{tabular}

Keterangan : hemoglobin darah pada anak usia 9-12 tahun

*Uji korelasi Rank spearman

Tabel 3 menunjukan bahwa terdapat korelasi yang bermakna antara dua variabel yang diuji yaitu antara sarapan pagi yang dihubungan dengan kadar hemoglobin $(\mathrm{p}=0,00, \mathrm{R}=0,359)$ dan protein ( $\mathrm{p}=0,024, \mathrm{R}=0,286$ ). Hal ini berarti semakin anak terbiasa sarapan dan terpenuhi asupan proteinnya maka semakin baik nilai hemoglobin.

\section{PEMBAHASAN}

Penelitian ini menunjukan bahwa terdapat 2 $(3,2 \%)$ anak yang tergolong anemia, sedangkan sebanyak $60(96,7 \%)$ anak memiliki nilai kadar hemoglobin normal. Menurut World Health Organization (WHO), prevalensi anemia didunia banyak ditemukan pada anak usia sekolah dasar. ${ }^{3}$ Semua subjek yang memiliki kebiasaan makan pagi sebanyak $21(33,8 \%)$ anak, yang tidak memiliki kebiasaan makan pagi sebanyak $5(8,0 \%)$ anak, dan yang memiliki sifat kadang-kadang makan pagi sebanyak $36(58,0 \%)$ anak. Anak yang memiliki kebiasaan makan pagi dapat meningkatkan konsentrasi belajar dan daya ingat lebih bagus dari pada anak yang tidak sarapan pagi. Anak yang sering melewatkan makan pagi memiliki asupan gizi secara signifikan lebih buruk setiap harinya. Makan pagi juga berperan terhadap pemenuhan gizi seimbang pada anak. Kebiasaan makan pagi memberikan kontribusi besar kepada energi harian dan asupan zat gizi pada anak. ${ }^{5,16}$

Asupan seng yang diketahui memiliki peranan penting dalam pembentukan kadar hemoglobin. Asupan seng yang berasal dari makanan bercampur dengan seng dari sekresi pankreas didalam lumen intestinal, lalu kemudian diabsorbsi di duodenum dan usus halus proksimal. Seng diabsobsi disepanjang usus halus, dan selanjutnya seng disirkulasikan berikatan dengan albumin dan macroglobulin, protein molekul rendah, histidin dan diangkut oleh transferin untuk masuk ke dalam aliran darah dan dibawa ke hati. ${ }^{13,28}$ Asupan zat gizi seng pada semua subjek penelitian sebar 62 anak (100\%). Angka yang terdapat didalam subjek penelitian ini lebih kecil dari jumlah yang dianjurkan menurut AKG (Angka Kecukupan Gizi). ${ }^{23}$ Asupan seng yang di konsumsi pada subjek penelitian ini sebagian besar diperoleh dari produk perikanan. Subjek penelitian ini juga sering mengkonsumsi ikan bandeng, udang, kepiting, kerang, ikan mujair, dan ikan kipper.

Sebanyak $59(95,1 \%)$ anak pada penelitian ini memiliki asupan zat gizi besi dibawah nilai AKG. Nilai yang dianjurkan AKG asupan besi untuk lakilaki adalah $13 \mathrm{~g} / \mathrm{hari}$ dan untuk perempuan adalah 20 $\mathrm{g} /$ hari. Zat besi digolongkan sebagai zat gizi esensial bagi pertumbuhan anak. Kekurangan asupan zat besi dapat menyebabkan timbulnya anemia pada anak. Zat besi bersama dengan protein membentuk hemoglobin yang terdapat dalam sel darah merah yang bertanggung jawab mengikat oksigen dan mendistribusikan keseluruh tubuh. Metabolisme besi adalah siklus yang kompleks antara penyimpanan transport penghancuran dan penggunaan kembali. Pengelolaan besi dalam tubuh adalah proses yang sangat dinamik. Besi diabsorpsi hampir diseluruh bagian usus halus. Hati mengeluarkan sejumlah apotransferin ke dalam kandungan empedu dan kemudian mengalir ke duodenum, ini terkait pada besi bebas dalam makanan membentuk transferrin. ${ }^{6}$

Semua subjek pada penelitian ini terdapat beberapa anak yang memiliki asupan vitamin $\mathrm{C}$ yang kurang yaitu sebesar 47 anak $(75,8 \%)$ dan anak yang memiliki asupan vitamin $C$ yang cukup sebesar 15 anak $(24,1)$. Beberapa penelitian menunjukan bahawa vitamin $\mathrm{C}$ memegang peran penting dalam proses penyerapan zat besi. Hal ini dikarenakan vitamin C berfungsi sebagai pereduksi ion feri menjadi ion fero yang merupakan suatu bentuk zat besi yang mudah diserap. Kombinasi menu yang terdiri dari sayuran hijau, protein hewani dan buah dapat memperbaiki kualitas menu sehingga dapat meningkatkan tingkat penyerapan zat besi dari makanan yang diserap. ${ }^{31}$

Terdapat $45(72,5 \%)$ anak memiliki asupan protein kurang dari AKG, angka ini juga lebih kecil dari yang di anjurkan $\mathrm{AKG}$, yaitu $56 \mathrm{~g} /$ hari untuk anak laki-laki dan $60 \mathrm{~g} / \mathrm{hari}$ untuk anak perempuan. Kekurangan protein merupakan salah satu faktor yang dapat menunjang terjadinya anemia, karena pembentukan hemoglobin darah juga membutuhkan protein yang cukup. Semua subjek memiliki asupan serat yang kurang memenuhi dari kebutuhan perhari pada anak sekolah dasar. Angka asupan serat yang di 
anjurkan AKG yaitu $28 \mathrm{~g} /$ hari untuk perempuan dan $30 \mathrm{~g} /$ hari untuk laki-laki.

\section{SIMPULAN}

Terdapat $2(3,2 \%)$ anak yang dalam termasuk kategori anemia. Terdapat $45(72,5 \%)$ anak yang memiliki asupan protein kurang dan $21(33,8 \%)$ anak yang termasuk dalam kategori terbiasa makan pagi. Terdapat hubungan antara kebiasaan makan pagi dan asupan protein dengan kadar hemoglobin pada anak usia 9 sampai 12 tahun.

\section{SARAN}

Penelitian selanjutnya diharapkan dapat dilakukan penelitian lebih lanjut dengan menggunakan variabel kecacingan dan cemaran timbal untuk mengetahui pengaruhnya terhadap kadar hemoglobin.

\section{UCAPAN TERIMAKASIH}

Puji dan syukur penulis panjatkan kehadirat Allah SAW atas segala rahmat dan kemudahan yang telah diberikan-nya. Penulis menyampaikan ucapan terimakasih kepada responden, bapak/ibu guru SDI Taqwiyatul Wathon semarang khususnya siswa-siswi kelas 4, 5, dan 6 yang telah bersedia menjadi subjek dalam penelitian ini. Ucapan terimakasih juga penulis sampaikan kepada enumerator dan Bapak Adryan Pramono, S.Gz., M.Si dan Bapak Binar Panunggal, S.Gz, MPH yang telah memperkanankan saya untuk mengambil sebagian datanya yang digunakan dalam penelitian ini.

\section{DAFTAR PUSTAKA}

1. Andarina, Dewi, Sumarmi, Sri. Hubungan Konsumsi Protein Hewani dan Zat Besi dengan Kadar Hemoglobin pada Balita Usia 13-36 Bulan. Indonesian Jurnal of Public Health. 2006;3(1):19-23.

2. Riset Kesehatan Dasar. 2014. Badan Penelitian dan Pengembangan Kesehatan Kementrian Kesehatan Republik Indonesia.

3. World Health Organization (WHO). Iron Deficiency Anaemia Assessment, Prevention and Control. A guide for programme managers. 2001

4. Manampiring, Aaltje E. Prevalesi Anemia dan Tingkat Kecukupan Zat Besi pada Anak Sekolah Dasar di Desa Minaesa Kecamtan Wori Kabupaten Minahasa Utara. Skripsi. Fakultas Kedokteran Univeristas Sam Ratulangi. 2008.

5. Rahfiludin MZ. Pengaruh suplementasi besi dan seng melalui makanan jajanan terhadap perubahan status tembaga pada anak sekolah dasar yang pendek. Semarang 2002.

6. Ayu, Tri. Hubungan Asupan Zat Besi dan Kadar Hemoglobin dengan Kesegaran Jasmani ( $\left.\mathrm{VO}_{2} \mathrm{MAX}\right)$ pada Remaja Putri di SMA Negeri 3 Semarang. Skripsi. Ilmu Gizi Fakultas Kedokteran 2009
7. Sugianto. Hubungan Kontribusi Zat Gizi Makanan Sekolah dengan Kadar Hemoglobin Murid SD Islam Integral Luqman Al-Hakim Purwodadi. Skripsi. Program Studi Ilmu Gizi Universitas Diponegoro. 2008

8. Indah Suci A. Status gizi berdasarkan pola makan pada anak sekolah dasar di kecamatan Pajeg Tangerang 2014.

9. Adi Murbawani, Etisa. Asupan Mikronutrien, Kadar Hemoglobin dan Kesegaran Jasmani Remaja Putri. Program Studi Ilmu Gizi Univrsitas Diponegoro. 2011;45(1)

10. Cole, Concard R. et.al. Zinc and Iron Deficiency and Their Interrelations in Low-Income African American and Hispanic Children in Atlanta. American Journal of Clinical Nutririon. 2010 ;91:1027-34

11. Zulaekah, Siti. The Effect of Iron, Vitamin C Supplementation, and Nutrition Education on The Increase of Hemoglobin Level Among Anemic School Children in Kecamatan Kartasura Kabupaten Sukoharjo. Tesis. Magister Gizi Masyarakat Universitas Diponegoro. 2007

12. Tandirerung, Utami Erina., Mayulu, Nelly., Kawengian, Shirley E.S. Hubungan Kebiasaan Makan Pagi dengan Kejadian Anemia pada Murid SD Negeri 3 Manado. Jurnal e-Biomedik (eBM). 2013;1(1):53-58.

13. Herman, Susilowati. Review on the problem of Zinc Defficiency, Program Prevention and Its Prospect. Media Peneliti dan Pengembangan Kesehatan. 2009;19(2):73-83.

14. Gibson, RS 2005, Principles of Nutritional Assessment, Oxford University Press new york, p. $443-453$.

15. Rolfes, Rady Sharon., Pinna, Kathryn., Whitney, Ellie. Understanding Normal and Clinical Nutrition, Eighth Edition. Belmont, USA: Cengage Learning. 2009.

16. Utami, Erina. Hubungan Kebiasaan Makan Pagi dengan Kejadian anemia pada Murid SD Negeri 3 Manado. Jurnal e-Biomedik (eBM). 2013;1(1):53-58

17. Ni Mhurchu. Effects of a free school breakfast programme on school attendance, achievement, psychosocial function. And nutrition: a stepped wedge cluster randomize trial. Biomed Central Public Health. 2011:10(738):1-6.

18. Thobib S. Perbedaan Kadar Hemoglobin Pada Mahasiswa Universitas Jenderal Soedirman Yang Melakukan Olahraga Futsal Pada Siang Hari Dan Malam Hari. Skripsi. Purwokerto: Fakultas Kedokteran Dan Ilmu-Ilmu Kesehatan Jurusan Keperawtan Universitas Jenderal Soedirman; 2012.

19. Wulandari, Sri Yulina., Yulianto, Bambang., Sukristiyo. Pola Sebaran Logam Berat $\mathrm{Pb}$ dan $\mathrm{Cd}$ di Muara Sungai Babon dan Seringin Semarang. Jurnal Ilmu Kelautan. 2008;13 (4):203-208.

20. Khanis, Abdul. Iron Deficiency With ${ }_{\mathrm{s}}$ TFR Parameter as a Risk Factor of Febrile Seizures. Tesis. Magister Ilmu Biomedik Univesitas Diponegoro. 2010.

21. Rahfiludin, Zen Mohammad. Pengaruh Suplementasi Besi dan Seng Melalui Makanan Jajanan terhadap 
Perubahan Status Tembaga pada Anak Sekolah Dasar yang Pendek. Tesis. Semarang: Program Pasca Sarjana Magister Ilmu Biomedik. 2002.

22. Rolfes, Rady Sharon., Pinna, Kathryn., Whitney, Ellie. Understanding Normal and Clinical Nutrition, Eighth Edition. Belmont, USA: Cengage Learning. 2009.

23. Arisman. 2004. Gizi dalam Daur Kehidupan: Buku Ajar Ilmu Gizi. Jakarta: Penerbit Buku Kedokteran EGC.

24. Sareen S.G., Jack L., James L., Groff. Advanced Nutrition and Human Metabolism Fifth Edition. Wadsworth. Belmont, CA 94002-3098 USA. 2009.

25. Turgut, S., Hacioglu, S., Emmungil, G., Keskin, A. Relation Between Iron Deficiency Anemia and Serum Levels of Copper, Zinc, Cadmium and Lead. Polish J. of Environ. Stud. 2009;18(2):273-277.
26. Roche A., Sun S. Human Growth: Assesment and Interpretation. United States of America. New York: Cambridge University Press. 2003.

27. Hidayat. Seng (Zinc) Essensial Bagi Kesehatan. Jurnal Kedokteran Trisakti. 2010;18(1):19-26.

28. Hijova, E. Metallothioneins and Zinc: Their Function and Interaction. BMJ. 2004;105(5-6):230-234.

29. Perdana, Fachrudin, Hardinsyah. Analisis Jenis, Jumlah, Dan Mutu Gizi Konsumsi Sarapan Anak Indonesia. Jurnal Gizi dan Pangan. 2013; 8(1): 39-46.

30. Zakiyah, Sofi. Hubungan Vitamin A dan Asupan Seng dengan Kejadian Anemia pada Ibu Hamil. Skripsi. Semarang: Ilmu Gizi Fakultas Kedokteran Universitas Diponegoro. 2006.

31. Endi Ridwan. Kajian Interaksi Zat Besi Dengan Zat Gizi Mikro Lain Dalam Suplementasi (Review Of Interactions Between Iron And Other Micronutrients In Supplementation). Penel Gizi Makan. 2012; 35(1): 49-54. 